\title{
Experimental hybridization of alpine and lowland forms of Boeckella dilatata, a calanoid copepod
}

\author{
ANDREA E. BYROM* , CAROLYN W. BURNS \& GRAHAM P. WALLIS \\ Department of Zoology, University of Otago, P.O. Box 56, Dunedin, New Zealand
}

\begin{abstract}
The freshwater calanoid copepod Boeckella dilatata Sars inhabits lakes and ponds of glacial origin in central and southern South Island, New Zealand. In lowland lakes and ponds, this copepod is small and transparent while in alpine bodies of water, it is larger and bright red. The life history traits of alpine and lowland populations of this copepod also differ. In this paper we present the results of experimental hybridization between individuals from an alpine and a lowland population. Crosses between a transparent, lowland morph of $B$. dilatata and a red, alpine morph produced viable $F_{1}$. Intermorph matings showed no sign of reduced clutch size in either alpine or lowland females. Back- and inter-crossing of the $F_{1}$ showed that this generation was fertile and that subsequent $F_{2}$ were viable. Clutch sizes of $F_{1}$ hybrid females backcrossed to lowland males, however, were significantly smaller than those of females in other $F_{1}$ crosses; in addition, a high variance in clutch size was observed in all $F_{1}$ crosses, which is also interpreted as reduced fitness. $F_{1}$ hybrid breakdown was also apparent from the observation that clutch sizes of females in backcrosses with a parental constitution of 25 per cent alpine were significantly smaller than clutch sizes of females in pure crosses. These observations are attributed to heritable differences in life history characteristics between alpine and lowland populations of B. dilatata. We conclude that the red alpine and transparent lowland morphs of this copepod are best regarded as conspecifics in the early stages of speciation and we discuss the results as they relate to current concepts of speciation. $F_{1}$ and $F_{2}$ offspring all showed red pigmentation of similar intensity to the original alpine parental generation and we conclude that either pigmentation in $B$. dilatata is a polygenic character with dominance or is induced by a factor present in the alpine water.
\end{abstract}

Keywords: Boeckella, copepod, genetic divergence, hybrid breakdown, hybridization, speciation.

\section{Introduction}

Investigations into life-history traits of geographically separated freshwater and marine zooplankton enable insights into genetic variation within and among natural populations, which may provide a basis for subsequent speciation. Freshwater zooplankton in particular have improved our understanding of the interaction beween genetic and ecological processes because of their short generation times and ease of manipulation (Mort, $1991 \mathrm{a}, \mathrm{b})$. The genetic basis of differences in lifehistory traits between geographically separated

*Correspondence: Department of Zoology, University of British Columbia, 6270 University Boulevard, Vancouver, B. C. V6T 1Z4, Canada. populations of marine and freshwater copepods has been the focus of recent research. Allan (1984) performed interbreeding experiments between populations of the freshwater cyclopoid Mesocyclops edax from Florida and Michigan to examine heritable lifehistory variation within the species and Wyngaard (1986) revealed considerable additive genetic variance in body size in the Florida population and in maturation time in the Michigan population. Differences between Florida and Michigan populations were interpreted by both of these authors as reflecting different responses to selection in two widely separated geographic localities. More recently, Wyngaard (1988) produced evidence of geographical variation in dormancy in $M$. edax, using interbreeding experiments between the Florida and Michigan populations. In populations of the marine harpacticoid copepod 
Tigriopus californicus, Burton (1987, 1990) demonstrated hybrid breakdown, using developmental time as a fitness parameter.

The freshwater calanoid copepod Boeckella dilatata Sars inhabits lakes and ponds of glacial origin in central and southern South Island, New Zealand (Jamieson, 1988). In lowland lakes and ponds, this copepod is less than $1.0 \mathrm{~mm}$ in prosomal length, is transparent ('white'), frequently carries approximately five eggs per clutch and breeds continuously throughout the year (Burns, 1979). In alpine bodies of water, B. dilatata is larger (prosomal length up to $1.5 \mathrm{~mm}$ ), bright red, generally produces ten or more eggs per clutch and produces overwintering resting eggs (Burns, 1988). The two 'morphs' are not sympatric anywhere throughout their natural range but are regarded currently as conspecifics, based on Bayly's (1964) revision of the taxonomic status of the genus Boeckella.

The present study forms part of a wider investigation of the genetic basis of differences between alpine and lowland morphs of $B$. dilatata. In this paper we determine the interbreeding capabilities of an alpine and a lowland population of this species, examining the fecundity of intermorph matings, and viability and fecundity of $F_{1}$ produced from these matings.

Examination of variability within the species at two polymorphic isozyme loci (Pep and Pgi), using the techniques of Hebert and Beaton (1989), reveals allele frequency differences among red and white populations which are on average no greater than population differences within morphs (A. E. Byrom, unpublished data). $B$. dilatata is associated only with glacial lakes and ponds which historically would have been connected (Jamieson, 1988). Consequently, the genetic basis of adaptive divergence that may have occurred since lowland and alpine populations of $B$. dilatata became isolated, is of interest if speciation is regarded as a result of population differentiation.

Failure of $B$. dilatata individuals of different morphs to copulate would preclude recognition of the two morphs as conspecifics under the biological species concept (BSC; Mayr, 1982), the recognition concept of species (RC; Paterson, 1985) and the cohesion species concept (CSC; Templeton, 1989). The production of inviable or sterile $F_{1}$, or extensive hybrid breakdown (characterized by a reduced mean and increased variance in clutch size of $F_{1}$ hybrids), would question the status of the two morphs of B. dilatata as conspecifics under the BSC and CSC. The phylogenetic species concept (Cracraft, 1983) would regard such hybridization data as irrelevant and would view the two morphs as distinct species because they are fully diagnosable on the basis of colour and clutch size.

\section{Materials and methods}

\section{Collection, rearing and design}

Red alpine $B$. dilatata $(\mathbf{R})$ were collected from $\mathrm{Gem}$ Lake $\left(169^{\circ} 06^{\prime} \mathrm{E} 45^{\circ} 34^{\prime} \mathrm{S}\right.$, altitude $\left.1400 \mathrm{~m}\right)$ on 17 January 1990 and were kept at $8^{\circ} \mathrm{C}$ (to slow their development) until a few days before the start of the experiment. Mortality during this period was less than 1 per cent. White lowland $B$. dilatata (W) were collected from Lake Hayes $\left(168^{\circ} 49^{\prime} \mathrm{E} 44^{\circ} 59^{\prime} \mathrm{S}\right.$, altitude $329 \mathrm{~m}$ ) on 10 March 1990 and were kept at $15^{\circ} \mathrm{C}$ until the start of the experiment. Copepods from both populations were fed to excess on concentrated suspensions of Cryptomonas sp. and Rhodomonas sp.; these algae are regarded as good foods for Boeckella (Burns \& Xu, 1990). The algae were cultured in a modified MBL medium (Stemberger, 1981) at $20^{\circ} \mathrm{C}$ in a $16 \mathrm{~h}$ light: $8 \mathrm{~h}$ dark regimen.

In this paper we follow Allan (1984) in using clutch size as a measure of fitness. Egg diameter does not vary substantially with body size in calanoid copepods (Maly, 1984), including B. dilatata (C. W. Burns, unpublished data), so clutch size was regarded as a suitable fitness parameter for the parental and subsequent $F_{1}$ generations. Twenty replicates of each of four parental generation $\left(\mathrm{P}_{1}\right)$ crosses were set up; two intramorph crosses and two intermorph crosses as follows: $\mathrm{W} \times \mathrm{W}$, $\mathrm{W} \times \mathrm{R}, \mathrm{R} \times \mathrm{W}$ and $\mathrm{R} \times \mathrm{R}$ (the first letter designating the female parent). The $\mathrm{W} \times \mathrm{R}$ cross is referred to as 'cross $\mathrm{A}$ ', and the $\mathrm{R} \times \mathrm{W}$ cross as 'cross $\mathrm{B}$ '. For each cross, one female and one male were placed in each of $2060-\mathrm{ml}$ jars, each jar containing $15 \mathrm{ml}$ of water. Intermorph crosses were carried out in a 50:50 mix of water from the two lakes. As soon as nauplii hatched, they were removed and placed in one of four communal containers (one communal container per cross).

After the $F_{1}$ reached maturity, 10 replicates of each of 14 possible classes of $F_{1}$ cross were set up (Table 1). $F_{1}$ generation pure and hybrid offspring produced from the four parental generation crosses were used in this part of the study; animals were chosen at random from the four communal containers in the previous experiment. One male and one female were placed in each of 10 jars for each of the $14 \mathrm{~F}_{1}$ crosses. Water in the jars was a mix of alpine and lowland water, in proportions determined by the origin of $F_{1}$ individuals present. The random selection of male and female pairs of $F_{1}$ crosses would include some sib-sib matings for the $\mathrm{R} \times \mathrm{R}, \mathrm{W} \times \mathrm{W}, \mathrm{A} \times \mathrm{A}$ and $\mathrm{B} \times \mathrm{B}$ crosses (crosses $1,2,13$ and 14). Based on the distribution of numbers of $F_{1}$ produced among the 20 single-pair matings within each of the four parental crosses, we calculate the expected proportions of sib-sib matings will be 10 per 
Table 1 Pure, back and hybrid crosses of $F_{1}$ generation Boeckella dilatata. $A=F_{1}$ hybrids from the $\mathrm{W} \times \mathrm{R}$ parental cross; $\mathrm{B}=\mathrm{F}_{1}$ hybrids from the $\mathrm{R} \times \mathrm{W}$ parental cross

\begin{tabular}{llccc}
\hline Pure cross & Backcross A & Backcross B & Interhybrid & Intrahybrid \\
\hline $1 \mathrm{R} \times \mathrm{R}$ & $3 \mathrm{~A} \times \mathrm{R}$ & $7 \mathrm{~B} \times \mathrm{R}$ & $11 \mathrm{~A} \times \mathrm{B}$ & $13 \mathrm{~A} \times \mathrm{A}$ \\
$2 \mathrm{~W} \times \mathrm{W}$ & $4 \mathrm{~A} \times \mathrm{W}$ & $8 \mathrm{~B} \times \mathrm{W}$ & $12 \mathrm{~B} \times \mathrm{A}$ & $14 \mathrm{~B} \times \mathrm{B}$ \\
& $5 \mathrm{R} \times \mathrm{A}$ & $9 \mathrm{R} \times \mathrm{B}$ & & \\
& $6 \mathrm{~W} \times \mathrm{A}$ & $10 \mathrm{~W} \times \mathrm{B}$ & & \\
\hline
\end{tabular}

cent, 8 per cent, 6 per cent and 10 per cent for the four crosses, respectively. These are low enough to discount the effects of inbreeding depression.

$B$. dilatata has six naupliar (N1-6) and six copepodite instars $(\mathrm{CI}-\mathrm{CVI})$, reaching maturity in the CVI instar. Eggs are carried in a clutch in an egg sac at the base of the abdomen for a few days before they hatch into nauplii (subitaneous eggs) or are shed (resting eggs). Clutch size of $B$. dilatata from Lake Hayes does not vary with temperature (range $8.5-18^{\circ} \mathrm{C}$ ) in the presence of adequate food (Jamieson \& Burns, 1988). Females can produce several clutches of eggs from one mating, and they generally mate very soon after moulting into the adult (CVI) instar, so it was necessary to ensure that they had not already been fertilized before being paired with a male. For $F_{1}$ crosses, immature $\mathrm{CV}$ females were always paired with adult males and were allowed to mature in the presence of their mate. All hybridization experiments were carried out in a constant temperature room at $15^{\circ} \mathrm{C}$, which is $\pm 2^{\circ} \mathrm{C}$ of the temperature experienced by both morphs at the time of their collection (Burns, 1979; R. Nichol, personal communication). Copepods were given an equal feeding regimen of $1.0 \mathrm{ml}$ concentrated Cryptomonas $\mathrm{sp}$. suspension $(5.0 \mathrm{mg}$ dry weight Cryptomonas sp. per litre) per jar every 2 days. Replicate jars from all the crosses were spatially randomized.

At 2-day intervals for a 45-day period, $\mathrm{P}_{1}$ and subsequent $F_{1}$ jars were checked for the following factors: (i) clutch production by the female, including the presence of infertile eggs (dead females were recorded but not replaced); (ii) condition of the male (males that died within the first 6 days were replaced); and (iii) number of nauplii present.

In $P_{1}$ crosses, each female was allowed to produce two clutches of offspring, and the number of nauplii produced from two broods was recorded for the 20 females in each cross. If a $P_{1}$ female did not produce any offspring in the 45-day period, she was omitted from subsequent analyses because she may have been post-reproductive (Jamieson \& Burns, 1988) and a failure to develop egg masses could not be regarded as a true indicator of the fitness of the morph. In $F_{1}$ crosses, offspring from a single clutch only were counted, as clutch size of Boeckella spp. does not vary significantly between early and late clutches (Jamieson $\&$ Burns, 1988). As soon as one clutch of offspring was produced by a female, the jar was put aside and placed on a lowered feeding regimen. Qualitative observations of $F_{2}$ survival were made for the first 3-5 days. As all $\mathrm{CV}$ females matured to stage CVI within a few days of one another (unlike the $\mathrm{P}_{1}$ experiments), it is unlikely that slight differences in maturation time would contribute significantly to a failure of any females to produce clutches. Thus if a female failed to produce offspring in the 45-day period, this was recorded as 'zero' and the two pure $\mathrm{F}_{1}$ crosses $(\mathrm{R} \times \mathrm{R}$ and $\mathrm{W} \times \mathrm{W}$; Table 1) provided a direct comparison with other $F_{1}$ back- and hybrid crosses. Females that died during $\mathrm{P}_{1}$ and $\mathrm{F}_{1}$ experiments were also excluded from subsequent analyses of clutch size.

To stabilize variation in clutch size within crosses, clutch size data were transformed by taking the square root of the clutch size per two broods for each $P_{1}$ female in the four crosses and the square root of the clutch size per single brood for each $\mathrm{F}_{1}$ female in the 14 crosses. All data were analysed initially by analysis of variance (ANOVA).

Pigmentation of $F_{1}$ and $F_{2}$ offspring. The colour of offspring from both intermorph and pure $\mathrm{P}_{1}$ crosses was observed during $F_{1}$ development and can be expressed in terms of the pigmentation of the parental generation. The colour of the $\mathrm{F}_{2}$ generation was noted for the first 3-5 days after the nauplii hatched. All observations of $F_{1}$ and $F_{2}$ pigmentation were based on visual assessment only.

Production of infertile egg masses. Production of infertile egg masses by $\mathrm{P}_{1}$ and subsequent $\mathrm{F}_{1}$ females was recorded for each cross. 


\section{$P_{1}$ clutch size analysis}

Influence of morph on clutch size. A one-factor ANOVA was used to determine the influence of female morphotype on clutch size. This analysis was followed by a Tukey's test, which groups together mean clutch sizes which are not significantly different from one another(Zar, 1984).

Relative influence of each sex on clutch size. A twofactor ANOVA was performed to determine which sex (male or female) had a significant effect on clutch size, with the two sexes as the two factors.

Influence of intermorph mating on clutch size. A twofactor ANOVA was performed to compare the influence of the female on clutch size, with the influence of intermorph mating on clutch size. The two factors were: (i) the morph of the female (red or white); and (ii) the type of cross (intermorph or pure cross).

\section{$F_{1}$ clutch size analysis}

A one-factor ANOVA was performed to determine whether there were any significant differences in mean clutch size among the 14 crosses. Further analysis of clutch sizes of $F_{1}$ females was performed using contrasts, to allow comparisons among various combinations of crosses and to compare groups of pooled means with other groups (Zar, 1984) (see Table 3).

\section{Results}

\section{Parental generation crosses}

Influence of morph on clutch size. Red (alpine) females produced significantly larger broods than white (lowland) females, whether mated with an alpine male or a lowland male (Table 2).

Relative influence of each sex on clutch size. Female morphotype had an influence on clutch size (d.f. 1, 1; $F=44.6 ; P=0.0001$ ), whereas male morphotype had no effect (d.f. 1,$1 ; F=1.4 ; P=0.24$ ).

Influence of intermorph mating on clutch size. Intermorph crosses $(\mathrm{R} \times \mathrm{W}$ and $\mathrm{W} \times \mathrm{R})$ did not differ from intramorph crosses (d.f. 1,$1 ; F=0.3 ; P=0.58$ ).

Pigmentation of the $F_{I}$ generation. Nauplii from the pure white (lowland) cross $(\mathrm{W} \times \mathrm{W})$ all lacked pigmentation and offspring from the pure red (alpine) matings $(\mathrm{R} \times \mathrm{R})$ were all as red as their parents. $\mathrm{F}_{1}$ hybrids from the intermorph $\mathrm{R} \times \mathrm{W}$ cross appeared as red as the alpine parental generation. Females involved in this cross always carried red-pigmented eggs and hatched nauplii were always red. $F_{1}$ hybrid nauplii from the intermorph $\mathrm{W} \times \mathrm{R}$ cross, like their lowland mother, always lacked pigmentation and females involved in this cross always carried non-pigmented eggs. At approximately the time that the nauplii metamorphosed to $\mathrm{CI}$, however, all the $\mathrm{F}_{1}$ hybrids from the $\mathrm{W} \times \mathrm{R}$ cross developed red pigmentation and, as adults, appeared as red as the alpine parents.

\section{$F_{1}$ generation crosses}

There was heterogeneity among mean clutch sizes of females in $\mathrm{F}_{1}$ crosses (d.f. 13, 110; $F=5.039$; $P=0.0001$; Fig. 1). Contrasting various pure crosses, backcrosses and hybrid crosses highlighted significant factors contributing to the variability in $F_{1}$ clutch size (Table 3).

Pigmentation of the $F_{2}$ generation. Visually, $\mathrm{F}_{2}$ nauplii from the $\mathrm{W} \times W \mathrm{~F}_{1}$ cross were as white as the $\mathrm{P}_{1}$ and $\mathrm{F}_{1}$ $B$. dilatata; nauplii from the $\mathrm{R} \times \mathrm{R}_{1}$ cross were as red as their parents and grandparents. Nauplii from backcrosses involving a lowland female and a hybrid male (crosses 6 and 10; Table 1) lacked pigmentation. We do not know if these nauplii developed red pigmentation on reaching the $\mathrm{CI}$ developmental stage. All other nauplii (from pure red and red hybrid mothers) appeared to be as red as the original alpine parental generation.

Infertile clutch production. When mated with a white (lowland) male (crosses 4 and 8; Table 1), some hybrid females produced infertile egg masses consisting of a sac of yolk with no recognizable eggs. These masses were not shed but appeared to be reabsorbed by the female and, a short time later, a new infertile mass was produced. Of the $10 \mathrm{~A}$. females mated with a white male (cross 4), four produced three or four infertile egg masses. Of the $10 \mathrm{~B}$ females mated with a white male (cross 8 ), seven produced at least one infertile mass; no females in other $F_{1}$ crosses produced them.

\section{Discussion}

Parental generation intra- and intermorph crosses of $B$. dilatata showed that the two populations can hybridize and produce viable offspring and that intermorph matings do not produce significantly smaller clutch sizes than intramorph matings. Thus under the BSC, 
Fig. 1 Mean clutch sizes of $F_{1}$ Boeckella dilatata females: pure, back- and hybrid crosses (see Table 1). (-) Pure red $(\mathrm{R} \times \mathrm{R})$ cross; $(\square)$ pure white $(\mathrm{W} \times \mathrm{W})$ cross; $(\mathbb{*})$ backcrosses involving A hybrids; $($ backcrosses involving B hybrids; ( $)$ inter- and intrahybrid crosses. Error bars indicate S.E.M.
Table 2 Results of comparisons of square-root transformed mean clutch sizes per two broods among alpine $(\mathrm{R})$ and lowland $(\mathrm{W})$ parental generation Boeckella dilatata females mated with alpine and lowland males

\begin{tabular}{|c|c|c|c|c|}
\hline Cross & $\mathrm{R} \times \mathrm{R}$ & $\mathrm{R} \times \mathrm{W}$ & $\mathrm{W} \times \mathrm{R}$ & $\mathrm{W} \times \mathrm{W}$ \\
\hline Back-transformed mean CS $/ 2$ broods & 25.20 & 20.70 & 11.18 & 10.65 \\
\hline
\end{tabular}

Tukey's multiple contrast test groupings; braces join means that are not significantly different at the $5 \%$ level.

$\mathrm{CS}=$ clutch size.

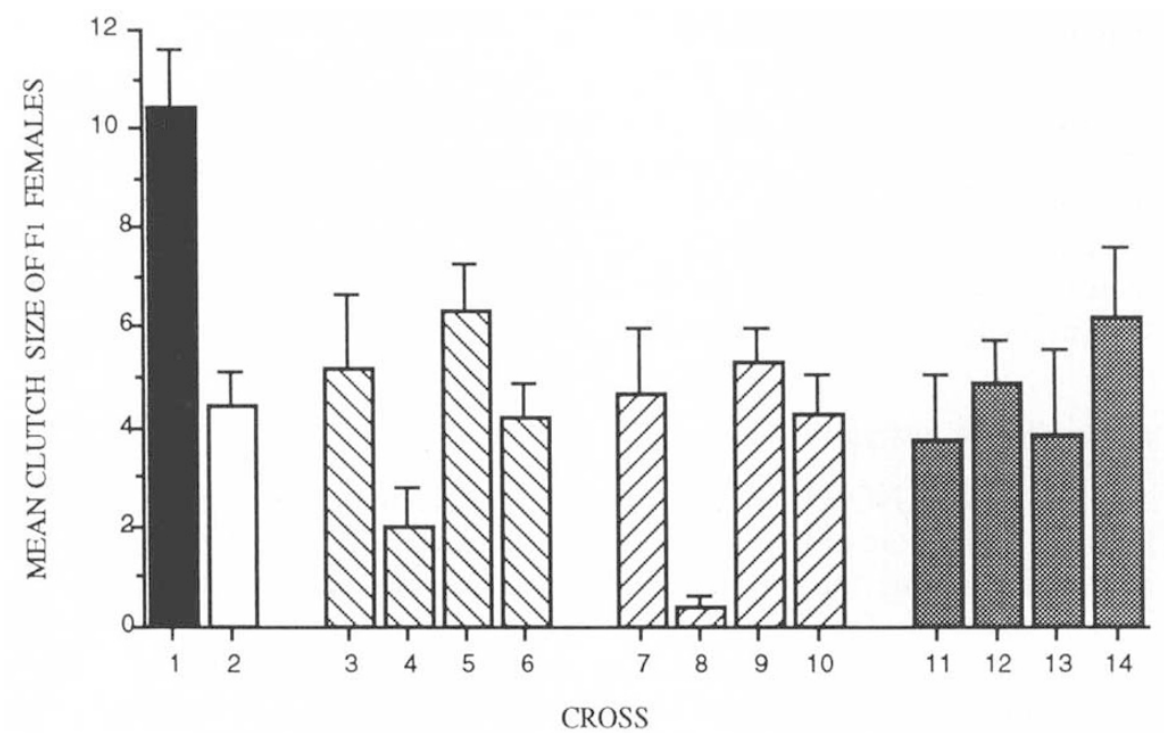

and certainly under Paterson's (1985) RC they should be regarded as conspecifics.

The observation that $B$. dilatata female morphotype in the $P_{1}$ generation crosses has a significant effect on clutch size whereas male morphotype has no effect, is in accordance with findings made using M. edax (Allan, 1984). Interestingly, clutch sizes of $F_{1}$ generation $B$. dilatata are not consistent with this general observation. In both types of backcross, clutch sizes of red females are not significantly different from those of white females and the origin of the female has little influence on the number of offspring produced. That is, fitness as measured by clutch size is reduced to the level of pure white crosses rather than being intermediate. However, non-hybrid male morphotype in both types of backcross has a significant effect on the clutch sizes of hybrid females.

The finding that clutch sizes of intermorph hybrid females are more like the low values of the $W \times W$ matings rather than intermediate to the $\mathrm{W} \times \mathrm{W}$ and $\mathrm{R} \times \mathrm{R}$ matings has two broad explanations: hybrid breakdown and/or dominance of genes controlling the trait of low clutch size in the lowland population. Contrasts $(\mathrm{k})-(\mathrm{p})$ show that the latter explanation is unlikely to be a major one (Table 3). Specifically, crosses with 25 per cent parental alpine genetic background produce even smaller clutches than the $\mathrm{W} \times \mathrm{W}$ $F_{1}$ cross and crosses with 50 per cent alpine genes and 75 per cent alpine genes have clutch sizes scarcely larger than the $\mathrm{W} \times W \mathrm{~W}_{1}$ cross. This strongly suggests that hybrid breakdown is the main cause of these observations.

In terms of the non-hybrid parent, clutch sizes of females in both types of backcross (A and B) show the same relative order: crosses involving red females have the largest clutch size, followed by those involving red males, then white females, with white males being smallest. This pattern is unlikely to occur by chance (1/4!; $P<0.05)$ and suggests consistency in the nature of $F_{1}$ hybrid breakdown.

As the two morphs of $B$. dilatata in nature differ in some aspects of their life history characteristics (e.g. the large clutch size and resting egg production of the red morph), it would be expected that there would be a 
Table 3 Results of contrasts among various combinations of crosses involving $F_{1}$ Boeckella dilatata showing significant factors contributing to variability in clutch sizes of $F_{1}$ females

\begin{tabular}{|c|c|c|c|}
\hline Comparison & $\begin{array}{l}\text { Cross } \\
\text { (see Table 1) }\end{array}$ & $\begin{array}{l}\text { Back-transformed } \\
\text { mean CS } \pm \text { S.E. }\end{array}$ & $\begin{array}{l}P \\
\text { (from contrast })\end{array}$ \\
\hline $\begin{array}{l}\text { (a) Red males in a pure cross }(R \times R) \\
\text { vs. red males mated with hybrid females }\end{array}$ & 1 vs. 3,7 & $\begin{array}{l}10.40 \pm 1.20 \text { vs. } \\
4.95 \pm 0.95\end{array}$ & 0.0003 \\
\hline $\begin{array}{l}\text { (b) White males in a pure cross }(\mathrm{W} \times \mathrm{W}) \\
\text { vs. white males mated with hybrid } \\
\text { females }\end{array}$ & 2 vs. 4,8 & $\begin{array}{l}4.44 \pm 0.65 \text { vs. } \\
1.19 \pm 0.45\end{array}$ & 0.0002 \\
\hline $\begin{array}{l}\text { (c) Red females in a pure cross }(\mathrm{R} \times \mathrm{R}) \text { vs. } \\
\text { red females mated with hybrid males }\end{array}$ & 1 vs. 5,9 & $\begin{array}{l}10.40 \pm 1.20 \text { vs. } \\
5.71 \pm 0.56\end{array}$ & 0.02 \\
\hline $\begin{array}{l}\text { (d) White females in a pure cross }(\mathrm{W} \times \mathrm{W}) \\
\text { vs. white females mated with hybrid } \\
\text { males }\end{array}$ & 2 vs. 6,10 & $\begin{array}{l}4.44 \pm 0.65 \text { vs. } \\
4.24 \pm 0.50\end{array}$ & 0.87 \\
\hline $\begin{array}{l}\text { (e) White males mated with hybrid } \\
\text { females vs. red males mated with } \\
\text { hybrid females }\end{array}$ & 4,8 vs. 3,7 & $\begin{array}{l}1.19 \pm 0.45 \text { vs. } \\
4.95 \pm 0.95\end{array}$ & 0.0001 \\
\hline $\begin{array}{l}\text { (f) Red females mated with hybrid males } \\
\text { vs. white females mated with hybrid } \\
\text { males }\end{array}$ & 5,9 vs. 6,10 & $\begin{array}{l}5.71 \pm 0.56 \text { vs. } \\
4.24 \pm 0.50\end{array}$ & 0.23 \\
\hline (g) Interhybrid vs. intrahybrid matings & 11,12 vs. 13,14 & $\begin{array}{l}4.33 \pm 0.76 \text { vs. } \\
5.06 \pm 0.94\end{array}$ & 0.59 \\
\hline $\begin{array}{l}\text { (h) A females in inter-and intrahybrid } \\
\text { matings vs. B females in inter- and } \\
\text { intrahybrid matings }\end{array}$ & 11,13 vs. 12,14 & $\begin{array}{l}3.83 \pm 0.85 \text { vs. } \\
5.56 \pm 0.82\end{array}$ & 0.05 \\
\hline (i) All A females vs. all B females & $\begin{array}{l}3,4,11,13 \text { vs. } \\
7,8,12,14\end{array}$ & $\begin{array}{l}3.81 \pm 0.62 \text { vs. } \\
4.14 \pm 0.64\end{array}$ & 0.67 \\
\hline (j) All A males vs. all B males & $\begin{array}{l}5,6,12,13 \text { vs. } \\
9,10,11,14\end{array}$ & $\begin{array}{l}4.74 \pm 0.47 \text { vs. } \\
4.92 \pm 0.55\end{array}$ & 0.76 \\
\hline $\begin{array}{l}\text { (k) Pure white cross }(\mathrm{W} \times \mathrm{W}) \text { vs. back- } \\
\text { crosses with parental constitution of } \\
25 \% \text { alpine }\end{array}$ & 2 vs. $4,6,8,10$ & $\begin{array}{l}4.44 \pm 0.65 \text { vs. } \\
2.76 \pm 0.43\end{array}$ & 0.03 \\
\hline $\begin{array}{l}\text { (1) Pure white cross }(\mathrm{W} \times \mathrm{W}) \text { vs. crosses } \\
\text { with parental constitution of } 50 \% \\
\text { alpine }\end{array}$ & 2 vs. $11,12,13,14$ & $\begin{array}{l}4.44 \pm 0.65 \text { vs. } \\
4.69 \pm 0.60\end{array}$ & 0.68 \\
\hline $\begin{array}{l}\text { (m) Pure white cross }(\mathrm{W} \times \mathrm{W}) \text { vs. back- } \\
\text { crosses with parental constitution of } \\
75 \% \text { alpine }\end{array}$ & 2 vs. $3,5,7,9$ & $\begin{array}{l}4.44 \pm 0.65 \text { vs. } \\
5.31 \pm 0.56\end{array}$ & 0.82 \\
\hline $\begin{array}{l}\text { (n) Pure red cross }(\mathrm{R} \times \mathrm{R}) \text { vs. } \\
\text { backcrosses with parental constitution } \\
\text { of } 25 \% \text { alpine }\end{array}$ & 1 vs. $4,6,8,10$ & $\begin{array}{l}10.40 \pm 1.20 \text { vs. } \\
2.76 \pm 0.43\end{array}$ & 0.0001 \\
\hline $\begin{array}{l}\text { (o) Pure red cross }(\mathrm{R} \times \mathrm{R}) \text { vs. crosses } \\
\text { with parental constitution of } 50 \% \\
\text { alpine }\end{array}$ & 1 vs. $11,12,13,14$ & $\begin{array}{c}10.40 \pm 1.20 \text { vs. } \\
4.69 \pm 0.60\end{array}$ & 0.0001 \\
\hline $\begin{array}{l}\text { (p) Pure red cross }(\mathrm{R} \times \mathrm{R}) \text { vs. backcrosses } \\
\text { with parental constitution of } 75 \% \\
\text { alpine }\end{array}$ & 1 vs. $3,5,7,9$ & $\begin{array}{l}10.40 \pm 1.20 \text { vs. } \\
5.31 \pm 0.56\end{array}$ & 0.001 \\
\hline
\end{tabular}

great deal of variation in clutch size among $F_{1}$ hybrids, as was the case (Figure 1). Lacey et al. (1983) and Gillespie (1974) have proposed models that estimate the fitness of individuals from the combined effects of mean and variance. As such a high variance is unexpected within a population (Gillespie, 1974;
Slatkin, 1974; Lacey et al., 1983), and is unstable (Burton, 1987, 1990), this may again indicate some breakdown in the $F_{1}$ generation hybrids.

The substantially smaller clutch sizes of hybrid females backcrossed to lowland (as opposed to alpine) males, and the high incidence of infertility in these 
matings, indicates that the trait is strongly influenced by the morph of the male. $F_{1}$ hybrid breakdown is particularly evident from these observations.

Because there was no difference in clutch size between females of the two different $F_{1}$ hybrid lines (originating from intermorph parental crosses $\mathrm{R} \times \mathrm{W}$ and $\mathrm{W} \times \mathrm{R}$ ), or among the clutch sizes of females mated with hybrid males, hybrids produced from both intermorph crosses probably had similar fitness. This, and the fact that $F_{1}$ hybrids produced reasonable numbers of offspring, suggests that it is best to continue regarding the red and white morphs of $B$. dilatata as conspecifics under the BSC. Further support for this conclusion comes from two polymorphic isozyme loci data from six B. dilatata populations (four red and two white populations, inclusive of the Gem Lake and Lake Hayes populations) (A. E. Byrom, unpublished data). This analysis revealed differences in allele frequencies among the six populations but morphological differences made little or no contribution to genetic differentiation within the species as a whole.

Two hypotheses can be proposed to explain the observed red pigmentation of $F_{1}$ and $F_{2} B$. dilatata. Firstly, red pigmentation of adult $F_{1}$ copepods produced from intermorph crosses may suggest that dominant nuclear genes are responsible for red pigmentation and this is supported by continuation of red pigmentation into the $\mathrm{F}_{2}$. The absence of $\mathrm{F}_{2} B$. dilatata with white or intermediate pigmentation (aside from those with white mothers) indicates that several loci are involved. Bocquet (1951) claims that in the harpacticoid copepod Tisbe, body pigmentation patterns in females are controlled by at least seven loci. Secondly, red pigmentation in $B$. dilatata may be environmentally induced by a factor present in the Gem Lake water (even at 25:75 dilution).

The non-pigmented nauplii produced by white $P_{1}$ and $F_{I}$ females crossed with red males suggests an additional maternal effect on the pigmentation of early developmental stages that disappears after approximately the final naupliar stage. Further research is required to investigate the physiological and genetic basis of pigmentation in $B$. dilatata and to determine selective forces operating to produce the bright red pigmentation observed in the alpine morph of this species.

The experimental procedure outlined in this paper could be regarded as a conservative test of conspecificity because females were not provided with a choice of males with which to mate. The two morphs of $B$. dilatata interbred freely, however, and produced a viable and fertile $F_{1}$ which, in turn, produced a viable $F_{2}$. Therefore, despite the observed indications of hybrid breakdown, under the BSC, and certainly under the $\mathrm{RC}$ and $\mathrm{CSC}$, the two morphs of $B$. dilatata should still be regarded as a single species. The observed hybrid breakdown suggests, however, that red and white populations of $B$. dilatata to some extent represent distinct coadapted gene pools.

Investigations such as these allow insights into genetic variation within and among natural populations, and into the genetic basis of adaptive divergence occurring among allopatric populations, the precursor of speciation.

\section{Acknowledgements}

We are grateful to Grace Wyngaard and Dolph Schluter for helpful comments on an earlier draft of the manuscript and to Brian Niven for statistical advice.

\section{References}

ALLAN, J. D. 1984. Life history variation in a freshwater copepod: evidence from population crosses. Evolution, 38, 280-291.

BAYLY, I. A. E. 1964. A revision of the Australasian species of the freshwater genera Boeckella and Hemiboeckella (Copepoda: Calanoida). Aust. J. Mar. Freshwater Res., 15, 180-238.

BOCQUET, C. 1951. Recherches sur Tisbe (=Idyaea) reticulata, n. sp. Essai d'analyse genetique du polychromatisme d'un Copepode Harpacticoide. Arch. Zool. Exp. Gen., 87, $335-416$.

BURNS, C. W. 1979. Population dynamics and production of Boeckella dilatata (Copepoda: Calanoida) in Lake Hayes, New Zealand. Arch. Hydrobiol., 54 (Suppl.), 409-465.

BURNS, C. W. 1988. Report on the aquatic fauna of the Umbrella Ecological District in the Waikaia Ecological Region. In: Dickinson, K. J. M. (ed.), Umbrella Ecological District Waikaia Ecological Region survey report for the New Zealand Protected Natural Areas programme. New Zealand Protected Natural Areas Programme No. 7. Department of Conservation, Wellington, New Zealand, pp. 61-65.

BURNS, C. W. AND XU, Z. 1990. Utilisation of colonial cyanobacteria and algae by freshwater calanoid copepods: survivorship and reproduction of adult Boeckella species. Arch. Hydrobiol., 117, 257-270.

BURTON, R. s. 1987. Differentiation and integration of the genome in populations of the marine copepod Tigriopus californicus. Evolution, 41, 504-513.

BURTON, R. S. 1990. Hybrid breakdown in developmental time in the copepod Tigriopus californicus. Evolution, 44, 1814-1822.

CRACRAFT, J. 1983. Species concepts and speciation analysis. Current Ornithology, 1, 159-187.

GILLESPIE, J. H. 1974. Natural selection for within-generation variance in offspring number. Genetics, 76, 601-606. 
HEBERT, P. D. N. AND BEATON, M. J. 1989. Methodologies for Allozyme Analysis Using Cellulose Acetate Electrophoresis: a Practical Handbook. University of Windsor, Windsor, Ontario.

JAMIESON, C. 1988. The biogeography of three Boeckella species (Copepoda: Calanoida) in New Zealand. Hydrobiologia, 164, 259-270.

JAMIESON, C. D. AND BURNS, C. w. 1988. The effects of temperature and food on copepodite development, growth and reproduction in three species of Boeckella (Copepoda: Calanoida). Hydrobiologia, 164, 235-257.

LACEY, E. P., REAL, L., ANTONOVICS, J. AND HECKEL, D. G. 1983. Variance models in the study of life histories. Am. Nat., 122, 114-131.

MALY, E. J. 1984. Dispersal ability and relative abundance of Boeckella and Calamoecia (Copepoda: Calanoida) in Australian and New Zealand waters. Oecologia, 62, 173-181.

MAYR, E. 1982. The Growth of Biological Thought. Belknap, Cambridge, Massachusetts.

MORT, M. A. 1991a. Bridging the gap between ecology and genetics: the case of freshwater zooplankton. Trends in Ecol. Evol., 6, 41-45.
MORT, M. A. 1991b. Ecological genetics of freshwater zooplankton: current research and future perspectives. Arch. Hydrobiol., 123, 129-141.

PATERSON, H. E. H. 1985. The recognition concepts of species. In: Vrba, E. S. (ed.), Species and Speciation. Transvaal Museum monograph 4. Transvaal Museum, Pretoria, pp. 21-29.

SlatKIn, M. 1974. Hedging one's evolutionary bets. Nature, 250, 704-705.

STEMBERGER, R. S. 1981. A general approach to the culture of planktonic rotifers. Can. J. Fish. Aquat. Sci., 38, 721-724.

TEMPLETON, A. R. 1989. The meaning of species and speciation: a genetic perspective. In: Otte, D. and Endler, J. A. (eds), Speciation and its Consequences. Sinauer Associates, Inc. Sunderland, Massachusetts, pp. 3-27.

WYNGAARD, G. A. 1986. Heritable life history variation in widely separated populations of Mesocyclops edax (Crustacea: Copepoda). Biol. Bull., 170, 296-304.

WYNGAARD, G. A. 1988. Geographical variation in dormancy in a copepod: evidence from population crosses. Hydrobiologia, 167/168, 367-374.

ZAR, J. H. 1984. Biostatistical Analysis, 2nd edn. PrenticeHall, Englewood Cliffs, NJ. 